\title{
Productivity and Nutritive Quality of Johnsongrass (Sorghum halepense) as Influenced by Commercial Fertilizer, Broiler Litter, and Interseeded White Clover (Trifolium repens)
}

\author{
Sandra L. Dillard, ${ }^{1}$ Laura E. Sturgeon, ${ }^{2}$ Walter F. Owsley, ${ }^{1}$ C. Wesley Wood, ${ }^{2}$ \\ James L. Holliman, ${ }^{3}$ and Russell B. Muntifering ${ }^{1}$ \\ ${ }^{1}$ Department of Animal Sciences, Auburn University, 210 Upchurch Hall, AL 36849-5415, USA \\ ${ }^{2}$ Department of Agronomy and Soils, Auburn University, 201 Funchess Hall, AL 36849-5412, USA \\ ${ }^{3}$ Black Belt Research and Extension Center, Auburn University, Marion Junction, AL 36759-3510, USA
}

Correspondence should be addressed to Russell B. Muntifering, muntirb@auburn.edu

Received 9 June 2011; Accepted 18 November 2011

Academic Editor: Horea Cacovean

Copyright ( 2012 Sandra L. Dillard et al. This is an open access article distributed under the Creative Commons Attribution License, which permits unrestricted use, distribution, and reproduction in any medium, provided the original work is properly cited.

\begin{abstract}
In the southeastern USA, there is an abundance of broiler litter from commercial poultry production that is available for use as fertilizer, but cropland and pastureland amended with broiler litter often exhibit greatly increased soil-test P. We evaluated productivity and nutritive quality of Johnsongrass (Sorghum halepense) that was interseeded with or without white clover (Trifolium repens) and which commercial fertilizer (ammonium nitrate and diammonium phosphate) or broiler litter was applied on the basis of soil-test P; broiler litter was supplemented with ammonium nitrate to be isonitrogenous with commercial fertilizer. Forage dry matter yield and foliar concentrations of crude protein, cell wall constituents, $\mathrm{P}, \mathrm{K}$, and $\mathrm{Cu}$ were not different among fertilizer treatments, and concentration of $\mathrm{Zn}$ was only slightly greater for forage amended with broiler litter than commercial fertilizer. Results indicate that broiler litter can be a cost-effective alternative to commercial fertilizer for warm-season forage production when applied on the basis of soil-test $\mathrm{P}$.
\end{abstract}

\section{Introduction}

Poultry production is a major agricultural industry in the southeastern USA, and significant quantities of broiler litter are generated and available for use as fertilizer for pasture and row crops. Within the state of Alabama alone, approximately 1.36 million metric tons of broiler litter are produced annually [1], over $90 \%$ of which is disposed through application to cropland and pastureland [2]. In areas of concentrated poultry production, soils often become concentrated with nutrients as a result of repeated land application of broiler litter over extended periods of time [3]. Studies have shown that repeated land application of animal manures to agricultural fields can potentially cause environmental problems [4]. Phosphorus runoff and resulting eutrophication is one of the most common environmental problems associated with use of organic fertilizers $[2,5]$.
High-producing warm-season forages have significant capacity for assimilating nutrients from land-applied broiler litter $[6,7]$. In the southeastern USA, application of broiler litter to Bermudagrass (Cynodon dactylon) pasture has been used successfully for producing high biomass yields, and, in doing so, reducing adverse effects of broiler litter application on soil quality [8]. Studies have shown that Johnsongrass (Sorghum halepense) can produce as much or more biomass than common Bermudagrass, making it an attractive candidate for nutrient management.

Broiler litter is commonly land-applied on the basis of crop requirement for $\mathrm{N}$; however, this practice has resulted in elevated concentrations of soil P [9]. Low nutrient concentration and bulk density compared with commercially available synthetic fertilizer make long-distance transportation of broiler litter cost-prohibitive. However, pressure compaction of broiler litter increases its bulk density without adversely 
affecting its nutrient concentration [10], conceivably making its transportation from areas of intensive poultry production to limited-resource agricultural areas more economically feasible [11]. Also, application of broiler litter on the basis of soil-test $\mathrm{P}$ may prevent accumulation of $\mathrm{P}$ in soils and thus minimize environmental hazards associated with land application of animal manures.

The objective of the research reported herein was to evaluate productivity and nutritive quality of Johnsongrass that was interseeded with or without white clover (Trifolium repens) and which isonitrogenous treatments of commercial fertilizer (diammonium phosphate), compacted broiler litter, or noncompacted broiler litter were applied on the basis of soil-test P.

\section{Materials and Methods}

2.1. Research Site. The experiment was conducted in the summers of 2007 and 2008 at the Black Belt Research and Extension Center in Marion Junction, AL $\left(32^{\circ} 28^{\prime} 50.29^{\prime \prime} \mathrm{N}\right.$ latitude, $87^{\circ} 15^{\prime} 26.61^{\prime \prime} \mathrm{W}$ longitude, $57 \mathrm{~m}$ above MSL). The Black Belt physiographic region is of special interest in the context of the current research because it is characterized by a resource-poor agricultural landscape with historically limited access to broiler litter from areas of concentrated poultry production. Twenty-four field plots $(3 \times 6 \mathrm{~m}$ each) consisting of Vaiden and Houston clay soils were demarcated and treated on June 8, 2007 with glyphosate (N-(phosphonomethyl) glycine) to kill existing vegetation. Plots were tilled on June 15 and seeded on June 18, 2007. Plots were organized into four blocks (replicates), each of which comprised six plots representing six experimental treatments. Soil nutrient ratings and values were determined, and fertilization recommendations were made on the basis of soil tests conducted by the Auburn University Soil Testing Laboratory.

2.2. Compaction of Broiler Litter. Broiler litter was collected from a poultry operation in Talladega County, AL, and transported to Auburn University. Initial moisture concentration in litter was determined using a model IR-200 moisture analyzer (Denver Instruments, Arvada, CO). Water was then added to and mixed with a portion of the litter in a concrete mixer to achieve a moisture concentration of approximately $40 \%$. Immediately after mixing, moistened litter was subjected to $192 \mathrm{MPa}$ of pressure for $1 \mathrm{~min}$ until 4 layers of litter were compacted into cubes that measured approximately $30.5 \times 30.5 \times 20 \mathrm{~cm}$. Cubes were stored for 5 days before they were chipped using a commercial mulch chipper, and then were transported with a load of noncompacted broiler litter to Marion Junction, AL, and applied to plots.

2.3. Forage Establishment, Management, and Harvesting. Johnsongrass (Sorghum halepense) was seeded into all plots at a recommended rate of $28 \mathrm{~kg} / \mathrm{ha}$, and ladino clover (Trifolium repens cv. "Regal Graze") was seeded into half of the plots in each block at a rate of $5.6 \mathrm{~kg} / \mathrm{ha}$ to achieve a $1: 4$ ratio of clover to Johnsongrass. Plots were fertilized on June 18, 2007 with compacted broiler litter (BL), noncompacted BL (BL-N), or commercial fertilizer (CF) such that each clover-status $\times$ fertilizer-source treatment was represented once in each block. The CF was a mixture of ammonium nitrate (34-0-0) and diammonium phosphate (18-46-0) that was formulated to provide the equivalent of $56.0 \mathrm{~kg} \mathrm{P}_{2} \mathrm{O}_{5}$ and $67.3 \mathrm{~kg} \mathrm{~N} / \mathrm{ha}$. Broiler litter application rate was determined on the basis of soil-test P, and litter-amended plots were supplemented with additional $\mathrm{N}$ from ammonium nitrate in order to meet the recommended rate of $\mathrm{N}$ application $(67.3 \mathrm{~kg} \mathrm{~N} / \mathrm{ha})$ and be isonitrogenous with CF. All fertilizer was applied by hand and soil-incorporated prior to initial planting. In May, 2008, fertilizer was hand-applied onto the soil surface but not incorporated so as to not damage plant tissues.

Primary-growth forage was harvested in each year of the experiment (August 9, 2007 and August 1, 2008) when Johnsongrass had reached a late vegetative (boot) stage of maturity, followed by a second harvest of vegetativeregrowth forage (October 2, 2007 and September 22, 2008). Forage was cut with a flail-chopping mower to leave an aboveground stubble height of approximately $10 \mathrm{~cm}$. Freshcut forage was weighed on a portable scale, and a sample from each plot was then placed into a teared paper bag and weighed. Samples were oven-dried at $60^{\circ} \mathrm{C}$ for 72 hours, and dry matter (DM) yield was calculated for each plot based on dry-weight data.

2.4. Laboratory Analyses. Dried, air-equilibrated samples were ground in a Wiley mill (Arthur H. Thomas Co., Philadelphia, PA) to pass a 1-mm screen, and final DM concentration was determined by oven drying at $100^{\circ} \mathrm{C}$ according to procedures of AOAC [12]. Forage N concentration was determined by the Kjeldahl procedure [12], from which crude protein $(\mathrm{CP})$ was calculated as $\mathrm{N} \times 6.25$. Concentrations of neutral detergent fiber (NDF), acid detergent fiber $(\mathrm{ADF})$, and acid detergent lignin (ADL) were analyzed by procedures of Van Soest et al. [13]. Forage samples were prepared for mineral analyses by dry-ashing, wet-digestion with $1 \mathrm{~N} \mathrm{HNO}_{3}$, and solubilization in $1 \mathrm{~N} \mathrm{HCl}$ [14], and concentrations of $\mathrm{P}, \mathrm{K}, \mathrm{Cu}$, and $\mathrm{Zn}$ were then determined by inductively coupled argon plasma (ICAP) spectroscopy (Spectro Ciros CCD, Germany).

2.5. Statistical Analysis. Data were analyzed using the PROC MIXED procedure (SAS Institute Inc., Cary, NC) for a complete block design with a $2 \times 3$ factorial arrangement of treatments (4 replicates per treatment). Independent variables included block (replicates), clover status, fertilizer source, and the clover-status $\times$ fertilizer-source interaction. Vegetative regrowth harvests were treated as repeated measures of primary harvests, and year was considered as a random effect in the statistical model. Treatment means were separated by the LSMEANS procedure (SAS Inst. Inc., Cary, NC) when protected by $F$-tests significant at $\alpha$ of 0.10 and are reported as least squares means $\pm \mathrm{SE}$. 


\section{Results}

3.1. Temperature and Precipitation. During the study period, monthly mean air temperatures were slightly higher than 30-year averages for Marion Junction, AL (Table 1). For the months of June, July, and August 2007, monthly precipitation was 11,46 , and $25 \%$ lower, respectively, than the 30 year average (Table 1). In 2008, June and July monthly precipitation was 13 and 53\% lower, respectively, than the 30-year average. Precipitation in August 2008 was 171\% higher than the 30 -year average; however, total precipitation in September 2008 was 96\% lower than the 30-year average for Marion Junction, AL. Total precipitation for the months during the experimental period was 61 and $17 \%$ below the 30-year average in 2007 and 2008, respectively.

3.2. Dry Matter Yield. No differences $(P=0.204)$ were observed between Johnsongrass and Johnsongrass-clover forage or among fertilizer-source treatments $(P=0.838)$ for DM yield (Table 2 ).

3.3. Crude Protein. Crude protein concentration (Table 2) was greater $(P=0.074)$ in Johnsongrass-clover than Johnsongrass forage but was not different $(P=0.602)$ among the three fertilizer-source treatments.

3.4. Cell Wall Constituents. Neutral detergent fiber concentration (Table 2$)$ was not different $(P=0.130)$ between Johnsongrass and Johnsongrass-clover forage or among fertilizersource treatments $(P=0.221)$. Similarly, concentration of ADF (Table 2$)$ was not different $(P=0.968)$ between Johnsongrass and Johnsongrass-clover forage or among fertilizersource treatments $(P=0.834)$. However, a forage $\times$ fertilizer source interaction $(P=0.098)$ was observed such that Johnsongrass fertilized with BL-N had lower $(P=0.081) \mathrm{ADF}$ concentration than CF-amended Johnsongrass. Also, Johnsongrass amended with $\mathrm{CF}$ had greater $(P=0.075)$ concentration of ADF than $\mathrm{CF}$-amended Johnsongrass-clover. Interseeding with clover had no effect $(P=0.737)$ on forage concentration of ADL (Table 2); also, fertilizer source did not affect $(P=0.342)$ ADL concentration. However, a forage $\times$ fertilizer source interaction $(P=0.051)$ was observed such that $\mathrm{ADL}$ concentration was greater $(P=0.013)$ in $\mathrm{CF}-$ than BL-N-amended Johnsongrass and within $\mathrm{CF}$ forages was greater $(P=0.041)$ for Johnsongrass than Johnsongrassclover.

3.5. Minerals. Foliar concentration of $\mathrm{P}$ (Table 2) was not different $(P=0.306)$ between forages or among fertilizersource treatments $(P=0.504)$. The Johnsongrass-clover mixture had greater $(P=0.002)$ foliar concentration of $\mathrm{K}$ (Table 2) than Johnsongrass, and BL-amended forages tended to have greater $(P=0.122)$ foliar concentration of $\mathrm{K}$ than $\mathrm{CF}$-amended forage. No difference $(P=0.870)$ was observed between Johnsongrass and Johnsongrass-clover in foliar $\mathrm{Zn}$ concentration (Table 2). Forages amended with CF had a lower foliar $\mathrm{Zn}$ concentration than both BL-N ( $P=$ $0.022)$ and $\mathrm{BL}-\mathrm{C}(P=0.064)$ treatments, but there was no
TABLe 1: Monthly mean air temperatures and precipitation for May-October 2007 and 2008 and 30-year averages for Marion Junction, AL.

\begin{tabular}{lcccccc}
\hline \multirow{2}{*}{ Month } & \multicolumn{3}{c}{ Mean, ${ }^{\circ} \mathrm{C}$} & \multicolumn{3}{c}{ Precipitation, mm } \\
& 2007 & 2008 & $\begin{array}{c}30-\mathrm{yr} \\
\text { avg. }\end{array}$ & 2007 & 2008 & $\begin{array}{c}30-\mathrm{yr} \\
\text { avg. }\end{array}$ \\
\hline May & 22 & 22 & 22 & 3 & 78 & 104 \\
June & 26 & 27 & 26 & 101 & 98 & 113 \\
July & 29 & 27 & 27 & 70 & 61 & 129 \\
August & 29 & 26 & 27 & 64 & 230 & 85 \\
September & 24 & 24 & 24 & 67 & 4 & 100 \\
October & 18 & 17 & 18 & 66 & 33 & 75 \\
\hline Total & & & & 371 & 504 & 606 \\
\hline
\end{tabular}

difference $(P=0.656)$ in foliar $\mathrm{Zn}$ concentration between the BL-N and BL-C treatments. However, foliar concentration of $\mathrm{Cu}$ (Table 2) was not different between forages $(P=0.261)$ or among fertilizer-source treatments $(P=0.459)$.

\section{Discussion}

Broiler litter used for fertilization of forages in 2007 contained $62 \% \mathrm{DM}, 3.75 \% \mathrm{~N}, 1.4 \% \mathrm{P}$, and $3.6 \% \mathrm{~K}$ on an ambient air-equilibrated basis. In 2008, broiler litter contained $80 \%$ $\mathrm{DM}$ and $3.4 \% \mathrm{~N}, 1.4 \% \mathrm{P}$, and $3.7 \% \mathrm{~K}$ on an ambient airequilibrated basis. Application rates of broiler litter based on soil-test $\mathrm{P}$ were equivalent to 1.358 and $1.752 \mathrm{~kg} / \mathrm{ha}$ in 2007 and 2008, respectively. This method of application required supplementation with ammonium nitrate to meet crop $\mathrm{N}$ requirements because experimental plots were deficient by 16.3 and $19.0 \mathrm{~kg} \mathrm{~N} /$ ha in 2007 and 2008, respectively. To meet Alabama Cooperative Extension System recommendations for $\mathrm{N}$, plots were supplemented with ammonium nitrate to achieve a total of $75 \mathrm{~kg} \mathrm{~N} /$ ha in both years.

Ball et al. [6] have reported that Johnsongrass can routinely produce between 4.500 and $11.200 \mathrm{~kg}$ of hay per ha over an entire growing season. In this experiment, DM yield averaged $6.856 \mathrm{~kg} / \mathrm{ha}$ for each harvest across years, forages, and fertilizer-source treatments. In the first year (2007), cumulative yield of primary growth and vegetative regrowth harvests averaged $10.078 \mathrm{~kg} / \mathrm{ha}$ across forages and fertilizersource treatments. In the second year (2008), the corresponding value for seasonal productivity was $17.344 \mathrm{~kg} / \mathrm{ha}$ across forages and fertilizer-source treatments. In 2007, total annual precipitation was $61 \%$ lower than the $30-y r$ average for Marion Junction, AL; however, forage production was still within the range of typical seasonal yields reported by Ball et al. [6], which illustrates the ability of Johnsongrass to withstand significant drought [15]. In 2008, total annual rainfall was only $17 \%$ below the $30-y r$ average, which provided more optimal conditions for growth. Total seasonal productivity of forages in 2008 illustrates the exceptionally high productivity potential of this warm-season grass.

Crude protein $(\mathrm{N} \times 6.25)$ is an important determinant of nutritive quality of forages. Johnsongrass interseeded with clover contained $6 \%$ more CP than Johnsongrass alone, 
TABLE 2: Yield of dry matter (DM) and foliar concentrations (DM basis) of crude protein (CP), neutral detergent fiber (NDF), acid detergent fiber (ADF), acid detergent lignin (ADL), and select minerals from Johnsongrass interseeded with $(+C)$ or without $(-\mathrm{C})$ white clover and amended with commercial fertilizer (CF), noncompacted broiler litter (BL-N), or compacted broiler litter (BL-C).

\begin{tabular}{|c|c|c|c|c|}
\hline & \multicolumn{4}{|c|}{ Fertilizer treatment } \\
\hline & $\mathrm{CF}$ & BL-N & $\mathrm{BL}-\mathrm{C}$ & Mean \\
\hline \multicolumn{5}{|c|}{ DM Yield $(\mathrm{kg} / \mathrm{ha})$} \\
\hline$-\mathrm{C}$ & 7.590 & 6.656 & 7.314 & 7.187 \\
\hline$+\mathrm{C}$ & 6.555 & 6.810 & 6.208 & 6.524 \\
\hline Mean & 7.073 & 6.733 & 6.761 & \\
\hline \multicolumn{5}{|l|}{$\mathrm{CP}(\%)$} \\
\hline$-\mathrm{C}$ & 10.2 & 10.0 & 9.7 & $9.9^{\mathrm{a}}$ \\
\hline$+\mathrm{C}$ & 10.6 & 10.5 & 10.4 & $10.5^{\mathrm{b}}$ \\
\hline Mean & 10.4 & 10.3 & 10.0 & \\
\hline \multicolumn{5}{|l|}{ NDF (\%) } \\
\hline$-\mathrm{C}$ & 63.2 & 63.8 & 65.4 & 64.1 \\
\hline$+\mathrm{C}$ & 64.2 & 66.8 & 67.2 & 66.0 \\
\hline Mean & 63.7 & 65.3 & 66.3 & \\
\hline \multicolumn{5}{|c|}{$\operatorname{ADF}(\%)^{\mathrm{c}}$} \\
\hline$-\mathrm{C}$ & 36.3 & 34.8 & 35.2 & 35.4 \\
\hline$+\mathrm{C}$ & 34.8 & 35.6 & 35.8 & 35.4 \\
\hline Mean & 35.5 & 35.2 & 35.5 & \\
\hline \multicolumn{5}{|c|}{$\operatorname{ADL}(\%)^{\mathrm{d}}$} \\
\hline$-\mathrm{C}$ & 3.4 & 3.0 & 3.2 & 3.2 \\
\hline$+\mathrm{C}$ & 3.1 & 3.2 & 3.2 & 3.2 \\
\hline Mean & 3.2 & 3.1 & 3.2 & \\
\hline \multicolumn{5}{|c|}{$\mathrm{P}(\mathrm{mg} / \mathrm{kg})$} \\
\hline$-\mathrm{C}$ & 0.17 & 0.18 & 0.18 & 0.18 \\
\hline$+\mathrm{C}$ & 0.17 & 0.17 & 0.18 & 0.17 \\
\hline Mean & 0.17 & 0.18 & 0.18 & \\
\hline \multicolumn{5}{|c|}{$\mathrm{K}(\mathrm{mg} / \mathrm{kg})$} \\
\hline$-\mathrm{C}$ & 0.85 & 0.99 & 0.93 & 0.92 \\
\hline$+\mathrm{C}$ & 1.01 & 1.09 & 1.09 & 1.06 \\
\hline Mean & 0.93 & 1.04 & 1.01 & \\
\hline \multicolumn{5}{|c|}{$\mathrm{Zn}(\mathrm{mg} / \mathrm{kg})$} \\
\hline$-\mathrm{C}^{\mathrm{c}}$ & 37.6 & 40.9 & 40.2 & 39.5 \\
\hline$+\mathrm{C}$ & 37.2 & 40.7 & 40.1 & 39.3 \\
\hline Mean & $7.4^{\mathrm{e}}$ & $40.8^{\mathrm{f}}$ & $40.1^{\mathrm{f}}$ & \\
\hline \multicolumn{5}{|c|}{$\mathrm{Cu}(\mathrm{mg} / \mathrm{kg})$} \\
\hline$-\mathrm{C}$ & 4.5 & 5.4 & 4.9 & 5.0 \\
\hline$+\mathrm{C}$ & 5.1 & 5.9 & 5.7 & 5.6 \\
\hline Mean & 4.8 & 5.6 & 5.3 & \\
\hline
\end{tabular}

$\overline{\mathrm{a}, \mathrm{b}}$ Clover treatment means without a common superscript differ $(P<0.10)$; $\mathrm{SE}=1.43, n=48$.

${ }^{\mathrm{c} C l o v e r}$ treatment $\times$ fertilizer treatment interaction $(P<0.10)$; $\mathrm{SE}=0.89$, $n=16$.

${ }^{\mathrm{d}}$ Clover treatment $\times$ fertilizer treatment interaction $(P<0.05)$; $\mathrm{SE}=0.58$, $n=16$.

e,f Fertilizer treatment means without a common superscript differ $(P<$ $0.10) ; \mathrm{SE}=2.05, n=32$.

which was expected because legumes normally have a higher concentration of protein than grasses. Alfalfa, for example, routinely contains approximately $20 \%$ or more CP, which is much higher than that in most forage grasses [16]. In the present study, mean foliar concentration of CP was $10.2 \%$ across forages and fertilizer-source treatments, which is more than adequate to support maintenance of a mature, nonlactating beef cow or modest daily liveweight gain in a growing beef steer [17]. Fertilizer source did not have an effect on $\mathrm{CP}$ concentration. Wood et al. [8] observed no difference in $\mathrm{CP}$ concentration in Bermudagrass that had been fertilized with ammonium nitrate or broiler litter, although CP concentration differed among forages receiving different rates of $\mathrm{N}$ application. In the current study, $\mathrm{N}$-application rates were uniform among all fertilizer-source treatments. Across years, forages, and fertilizer-source treatments, regrowth harvests contained $9 \%$ less CP than primary-growth harvests. Similarly, Johnson et al. [18] reported that CP concentration declined over a growing season in Bermudagrass that had been harvested multiple times.

Neutral detergent fiber consists of partially and nonuniformly digestible fractions of total cell-wall constituents that are inversely related to voluntary DM intake, whereas ADF includes the least digestible and indigestible cell-wall constituents that are inversely related to DM digestibility [16]. Foliar concentration of NDF across forages and fertilizersource treatments was $65.1 \%$ in the present study. Similarly, Adeli et al. [19] reported a range of 63.9 to $66.7 \% \mathrm{NDF}$ in Johnsongrass that had been fertilized with swine effluent. Neutral detergent fiber concentrations were not different between Johnsongrass and Johnsongrass-clover forages or among fertilizer-source treatments. Previous studies have shown a significant decrease in NDF concentration in Bermudagrass grown in mixture with a legume [20, 21], consistent with the agronomic generalization that concentration of NDF in legumes is typically lower than that of grasses when compared at comparable stages of physiological maturity [16].

Foliar concentration of ADF was 35.4\% across forages and fertilizer-source treatments in the present study. Similarly, Adeli et al. [19] observed a mean concentration of $39.2 \%$ ADF in Johnsongrass across multiple fertilizerapplication rates, harvests, and years. No fertilizer-source or forage treatment effects were observed for ADF concentration in the present study, in agreement with Adeli et al. [19] who reported that fertilizer source had no effect on ADF concentration in Johnsongrass. Within the Johnsongrass treatment, forage amended with commercial fertilizer had $5 \%$ greater ADF concentration than that amended with noncompacted broiler litter. However, this difference, while statistically significant, would not be expected to have a material effect on in vivo digestibility by the ruminant animal. Similarly, Johnsongrass fertilized with commercial fertilizer had 5\% greater ADF concentration than Johnsongrassclover forage, but this difference is probably too small to predict a material effect on digestibility in the live animal.

Lignin is an indigestible polyphenolic compound that is covalently bound via ester and ethereal linkages with structural carbohydrates in the secondary cell wall. It is a major protractor of forage DM digestibility in vivo because of the negative effect of lignification on digestibility of NDF and $\mathrm{ADF}$, of which ADL is a structural and analytical subset [16]. Foliar concentration of ADL was 3.2\% across all harvests, years, forage, and fertilizer-source treatments in the present study and was not different between forage or among fertilizer-source treatments. 
Relative feed value (RFV) is calculated by reference to a digestible DM intake that has been adopted to standardize a mature legume forage (e.g., full-bloom alfalfa) containing $53 \% \mathrm{NDF}$ and $41 \%$ ADF to an RFV of 100 [22]. As such, it integrates intake and digestibility predicted from concentrations of NDF and ADF, respectively, into a single index that is used widely for describing forage nutritive quality and determining market value of grass and legume hays in the USA and Canada [23]. Mean RFV was 87.9 and was not different between Johnsongrass and Johnsongrass-clover forages or among fertilizer-source treatments. As such, nutritive quality of forage in the present study is estimated to be approximately $88 \%$ of that of a medium-quality alfalfa hay. By comparison, Franzluebbers et al. [24] reported that Coastal Bermudagrass ranged in RFV from 85 to 100 in their study.

Foliar concentration of $\mathrm{P}$ was not different between Johnsongrass and Johnsongrass-clover forages or among fertilizer-source treatments. Previous reports have indicated that $\mathrm{P}$ concentrations are generally lower in legumes than grasses [25]. Additionally, Wood et al. [8] reported no difference in concentrations of $\mathrm{P}$ between Bermudagrass that had been fertilized with broiler litter or ammonium nitrate.

Foliar K concentration was not different between Johnsongrass and Johnsongrass-clover forages or among fertilizer-source treatments concentrations but tended to be greater in forages amended with broiler litter than commercial fertilizer. Wood et al. [8] reported 38\% greater $\mathrm{K}$ concentration in Bermudagrass receiving broiler litter than ammonium nitrate. Also, Johnsongrass-clover forage contained $12 \%$ more foliar $\mathrm{K}$ than Johnsongrass, in agreement with Whitehead et al. [25] who reported greater concentrations of foliar $\mathrm{K}$ in white clover than in common grasses. This finding, in conjunction with the observed increase in concentration of CP in the Johnsongrass-clover treatment, suggests that there may have been a sufficient amount of clover to alter at least some of the elemental compositional characteristics of the mixed-species treatment, even though the clover component may not have achieved its full growth potential.

One of the advantages of organic fertilizers over commercial fertilizer is their content of microelements that benefit plant productivity and nutrition of the grazing animal. However, it is important to monitor these for possible accumulation in soil and potential toxicity to livestock and humans [26]. Kingery et al. [4] reported that plant tissue samples collected from tall fescue (Lolium arundinacea) pastures receiving annual applications of broiler litter for 15 to 28 years had greater concentrations of $\mathrm{Cu}$ and $\mathrm{Zn}$ than unlittered pastures. Broiler litter can contain elevated concentration of $\mathrm{Cu}$ because it is used as an additive in poultry feed. However, foliar concentration of $\mathrm{Cu}$ did not differ between forages or fertilizer-source treatments in the present study, in agreement with previous studies on Bermudagrass fertilized with broiler litter and ammonium nitrate [8]. Zinc is a component of several key metalloenzymes that is routinely added to poultry feed and may be excreted at relatively high concentrations in fecal material [27]. Forages receiving commercial fertilizer had approximately $8 \%$ lower concentration of $\mathrm{Zn}$ than those receiving the broiler litter treatments, in contrast to findings by Wood et al. [8] who reported no difference in foliar concentrations of $\mathrm{Zn}$ in Bermudagrass fertilized with either broiler litter or ammonium nitrate. Foliar concentrations of $\mathrm{Cu}$ and $\mathrm{Zn}$ in the present study are within the range of requirements and well below the maximum tolerable limits for these minerals in cattle, sheep, and horses [28].

\section{Conclusions}

Results of this study indicate that pressure-compacted broiler litter supported productivity and nutritive quality of Johnsongrass that were comparable to those from noncompacted broiler litter. Also, broiler litter applied on the basis of soiltest $\mathrm{P}$ and supplemented with ammonium nitrate to meet crop $\mathrm{N}$ requirement supported productivity and nutritive quality of Johnsongrass comparable to that from commercial fertilizer. Pressure compaction may enable economical transportation of broiler litter from areas of intensive poultry production to resource-poor agricultural areas, providing limited-resource farmers with a cost-effective alternative to commercial fertilizer while at the same reducing P loading onto soils in areas of intensive poultry production.

\section{References}

[1] C. C. Mitchell and J. O. Donald, The Value and Use of Poultry Manures as Fertilizer, Alabama Cooperative Extension System, Auburn, Ala, USA, 1999.

[2] D. R. Edwards and T. C. Daniel, "Environmental impacts of On-Farm poultry waste disposal. A review," Bioresource Technology, vol. 41, no. 1, pp. 9-33, 1992.

[3] W. L. Kingery, C. W. Wood, D. P. Delaney, J. C. Williams, and G. L. Mullins, "Impact of long-term land application of broiler litter on environmentally related soil properties," Journal of Environmental Quality, vol. 23, no. 1, pp. 139-147, 1994.

[4] W. L. Kingery, C. W. Wood, D. P. Delaney, J. C. Williams, G. L. Mullins, and E. van Santen, "Implications of long-term land application of poultry litter on tall fescue pastures," Journal of Production Agriculture, vol. 6, pp. 390-395, 1993.

[5] B. H. Wood, C. W. Wood, K. H. Yoo, K. S. Yoon, and D. P. Delaney, "Seasonal surface runoff losses of nutrients and metals from soils fertilized with broiler litter and commercial fertilizer," Journal of Environmental Quality, vol. 28, no. 4, pp. 1210-1218, 1999.

[6] D. M. Ball, C. S. Hoveland, and G. D. Lacefield, Southern Forages, Potash and Phosphate Institute, Norcoss, Ga, USA, 4th edition, 2007.

[7] G. S. Fraps and J. F. Fridge, The Chemical Composition of Forage Grass of the East Texas Timber Country, Texas Agricultural Experiment Station Bulletin no. 582, College Station, Tex, USA, 1940.

[8] C. W. Wood, H. A. Torbert, and D. P. Delaney, "Poultry litter as a fertilizer for bermudagrass: effects on yield and quality," Journal of Sustainable Agriculture, vol. 3, pp. 21-36, 1993.

[9] A. N. Sharpley, S. J. Smith, and W. R. Bain, "Nitrogen and phosphorus fate from long-term poultry litter applications to Oklahoma soils," Soil Science Society of America Journal, vol. 57, no. 4, pp. 1131-1137, 1993.

[10] L. E. Sturgeon, Fertilizer value of densified broiler litter, M.S. thesis, Auburn University, Auburn, Ala, USA, 2008. 
[11] K. P. Paudel, M. Adhikari, and N. R. Martin, "Evaluation of broiler litter transportation in northern Alabama, USA," Journal of Environmental Management, vol. 73, no. 1, pp. 1523, 2004.

[12] AOAC, Official Methods of Analysis, Association of Official Analytical Chemists, Washington, DC, USA, 16th edition, 1995.

[13] P. J. van Soest, J. B. Robertson, and B. A. Lewis, "Methods for dietary fiber, neutral detergent fiber, and nonstarch polysaccharides in relation to animal nutrition," Journal of Dairy Science, vol. 74, no. 10, pp. 3583-3597, 1991.

[14] N. V. Hue and C. E. Evans, Procedures Used for Soil and Plant Analysis by the Auburn University Soil Testing Laboratory, Alabama Agricultural Experiment Station, Auburn University, Auburn, Ala, USA, 1986.

[15] C. G. McWhorter, "Epicuticular wax on Johnsongrass (Sorghum halepense) leaves," Weed Science, vol. 41, no. 3, pp. 475-482, 1993.

[16] P. J. van Soest, Nutritional Ecology of the Ruminant, Cornell University Press, Ithaca, NY, USA, 2nd edition, 1994.

[17] NRC, National Research Council. Nutrient Requirements of Beef Cattle, National Academy Press, Washington, DC, USA, 1996.

[18] C. R. Johnson, B. A. Reiling, P. Mislevy, and M. B. Hall, "Effects of nitrogen fertilization and harvest date on yield, digestibility, fiber, and protein fractions of tropical grasses," Journal of Animal Science, vol. 79, no. 9, pp. 2439-2448, 2001.

[19] A. Adeli, K. R. Sistani, M. F. Bal'a, and D. E. Rowe, "Phosphorus dynamics in broiler litter-amended soils," Communications in Soil Science and Plant Analysis, vol. 36, no. 9-10, pp. 10991115, 2005.

[20] W. C. Stringer, B. C. Morton, and B. W. Pinkerton, "Row spacing and nitrogen: effect on alfalfa-bermudagrass quality components," Agronomy Journal, vol. 88, no. 4, pp. 573-577, 1996.

[21] B. Sleugh, K. J. Moore, J. R. George, and E. C. Brummer, "Binary legume-grass mixtures improve forage yield, quality, and seasonal distribution," Agronomy Journal, vol. 92, no. 1, pp. 24-29, 2000.

[22] J. G. Linn and N. P. Martin, Forage Quality Tests and Interpretation, University of Minnesota Extension Service, St. Paul, Minn, USA, 1989.

[23] J. C. Lin, M. Nosal, R. B. Muntifering, and S. V. Krupa, "Alfalfa nutritive quality for ruminant livestock as influenced by ambient air quality in west-central Alberta," Environmental Pollution, vol. 149, no. 1, pp. 99-103, 2007.

[24] A. J. Franzluebbers, S. R. Wilkinson, and J. A. Stuedemann, "Bermudagrass management in the Southern Piedmont: trace elements in soil with broiler litter application," Journal of Environmental Management, vol. 33, no. 2, pp. 778-784, 2004.

[25] D. C. Whitehead, K. M. Goulden, and R. D. Hartley, "The distribution of nutrient elements in cell wall and other fractions of the herbage of some grasses and legumes," Journal of the Science of Food and Agriculture, vol. 36, pp. 311-318, 1985.

[26] M. E. Ensminger and C. G. Olentine Jr., Feeds and Nutrition, Enseminger Publication Company, Clovis, Ca, USA, 1st edition, 1978.

[27] Z. Yi, E. T. Kornegay, and D. M. Denbow, "Supplemental microbial phytase improves zinc utilization in broilers," Poultry Science, vol. 75, no. 4, pp. 540-546, 1996.

[28] L. L. Berger, Salt and Trace Minerals for Livestock, Poultry and Other Animals, Salt Institute, Alexandria, Va, USA, 5th edition, 1993. 

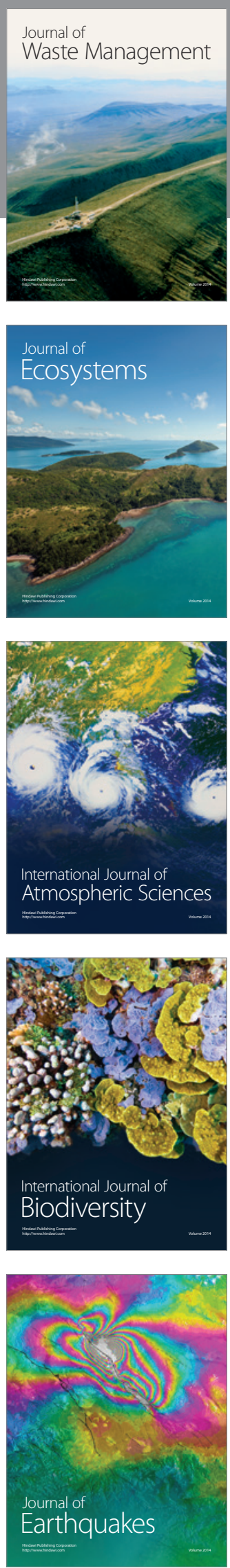
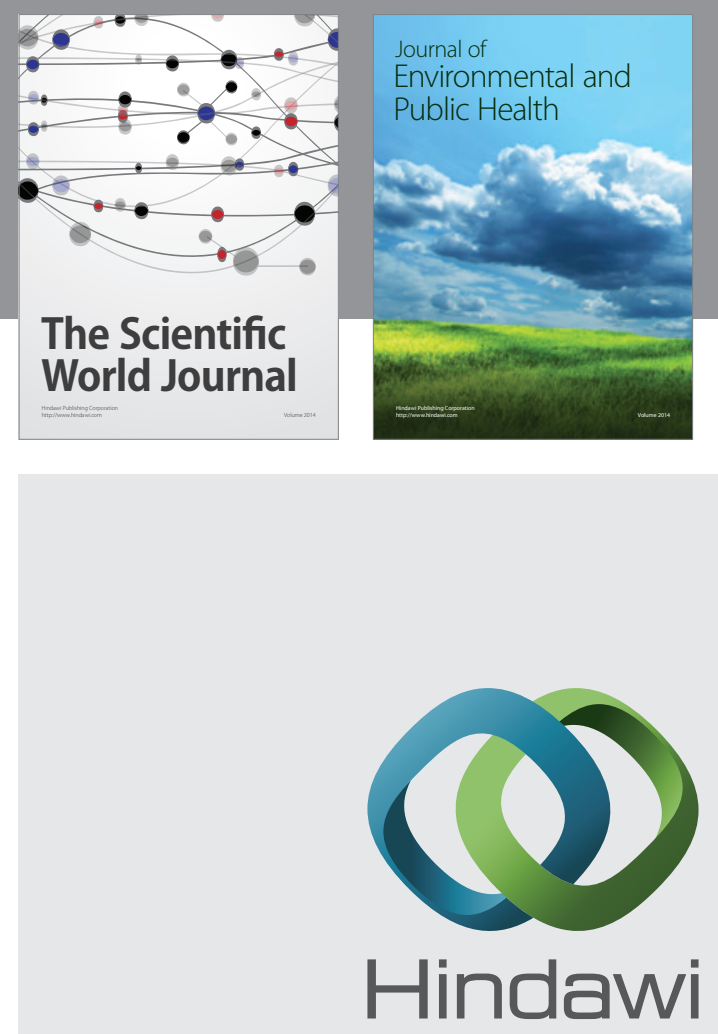

Submit your manuscripts at

http://www.hindawi.com
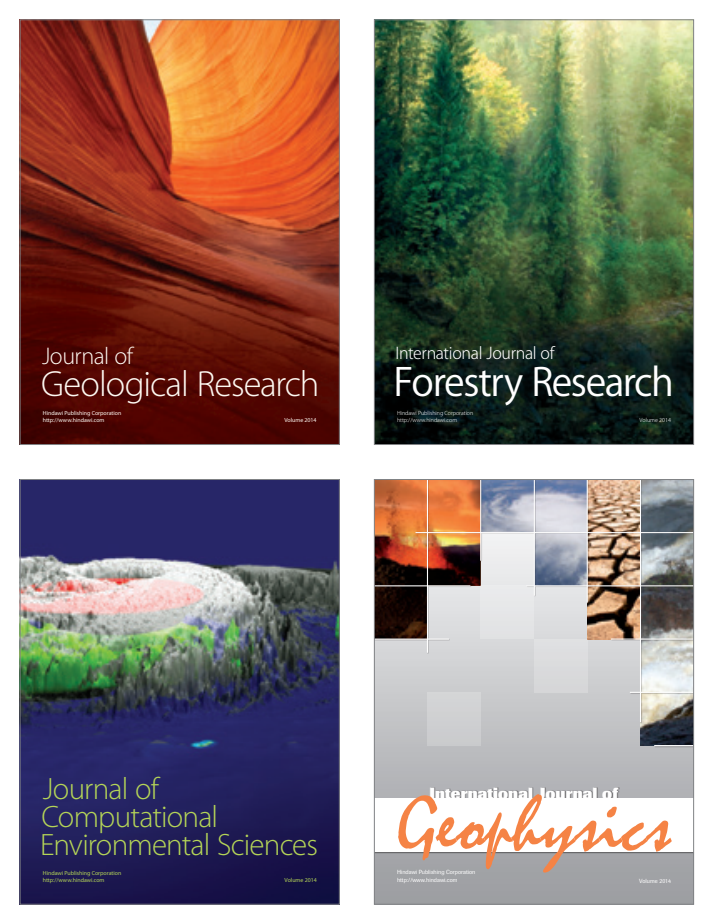
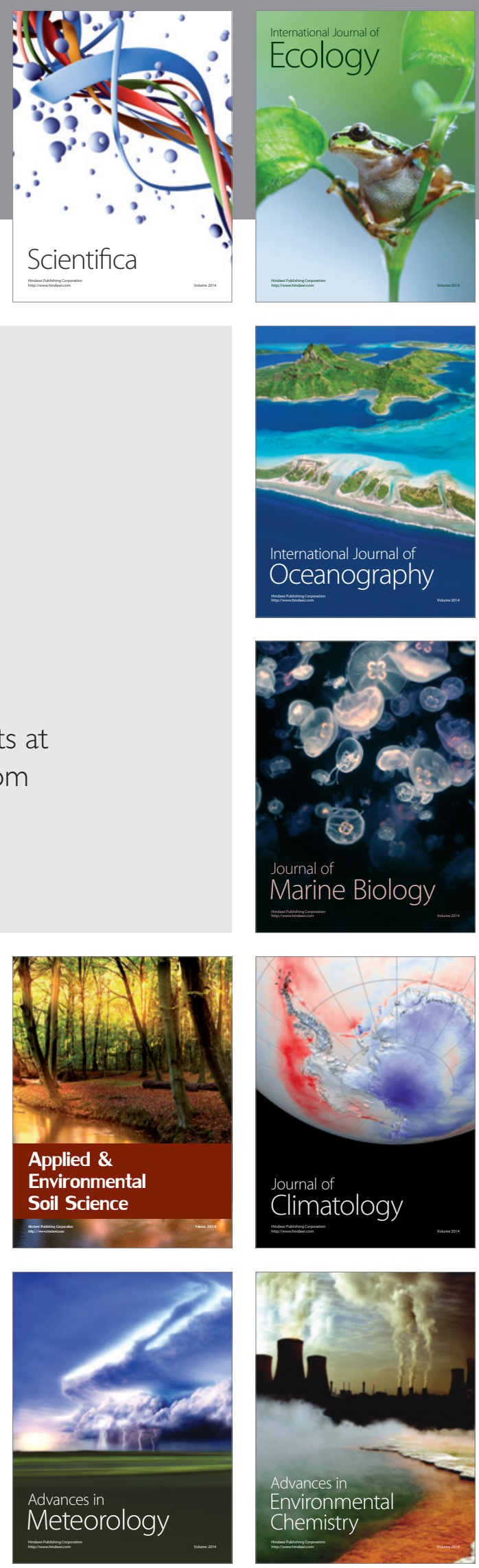